\title{
PENINGKATAN PEMAHAMAN KONSEP BILANGAN MELALUI BERMAIN ANGKLUNG
}

\author{
Dini Nurmalina Firsty, Myrnawati C.H, Hapidin \\ Universitas Negeri Jakarta \\ dininurmalina@yahoo.co.id,myrnawati48@gmail.com, hapidin1964@gmail.com
}

\begin{abstract}
The purpose of this study is to describe the process and results of angklung play activities to improve understanding of the concept of children under five in early childhood and whether angklung play can improve understanding of the concept of children in early childhood in 2017. Respondents in this study were 18 children from the group B PAUD Alfani in2017. The research method used is a model of Kemmis \& Taggart spiral action research consisting of: (a) planning, (b) action and observation, and (c) reflection. Instruments used in this study are field notes, interviews, and documentation. Scores of understanding data on economic concepts in children are analyzed quantitatively and qualitatively. The result of the data shows that the concept of learning in children increases from pre-cycle to first cycle and second cycle. Based on the observation of the action that has been done on the data given at the incidence rate $40.09 \%$, and in the first cycle to $59.41 \%$ and then increased in the second cycle of $85.61 \%$. The results ofthis study are (1) angklung playing activities can improve concept understanding in children group B PAUD Alfani in 2017, (2) concept comprehension score in children group B PAUD Alfani year 2017 increase from precycle to first cycle and first cycle to second cycle.
\end{abstract}

Keywords: number sense, angklung play, children aged 5-6 years

\section{A. PENDAhULUAN}

Pembelajaran untuk anak usia dini memegang peranan yang sangat penting penting bagi pembentukan dan sikap belajar pada tahap yang lebih lanjut. Keberhasilan belajar pada tahap awal sangat menentukan keberhasilan belajar pada tahap berikutkan. Juga sebaliknya, kegagalan belajar pada tahap awal merupakan penyebab paling besar terhadap kegagalan belajar pada tahap berikutnya. Pada tahun 1992 National Association for The Educationof Young Children (NAEYC) mengemukakan bahwa masa-masa awal kehidupan seorang anak merupakan masa-masanya belajar, "early years are early learning years". Hal ini disebabkan bahwa selama rentang waktu usia dini, anak mengalami berbagai pertumbuhan dan perkembangan yang sangat cepat dan pesat pada berbagai aspek.

Pada periode hampir seluruh potensi anak mengalami masa peka untuk tumbuh dan berkembang secara cepat dan hebat.
Oleh karena itu pada masa ini anak sangat membutuhkan stimulasi dan rangsangan dari lingkungannya. Keberhasilan belajar dipengaruhi oleh berbagai faktor, salah satu di antaranya adalah kemampuan guru dalam menciptakan dan merancang kegiatan pembelajaran yang kondusif.

Menurut penelitian yang dilakukan oleh Pirjo Aunio mengatakan bahwa "the child needs to know what objects are to be counted (i.e., classification skills) and count all the included items once and only once (i.e., one-to-one correspondence). In addition, depending on the task, the child mightneed todecide based onthe counting results which of the sets has more or less than the others (i.e., comparison and seriation skills)." Anak perlu tahu benda apa yang menjadi dihitung (yaitu, keterampilan classication) dan menghitung semua item yang disertakan sekali dan hanya sekali (yaitu, satu - ke - satu 
korespondensi). Selain itu, tergantung pada tugas, anak mungkin perlu memutuskan berdasarkan hasil penghitungan yang satu set memiliki lebih atau kurang dari yang lain (yaitu, perbandingan dan keterampilan seriation).

Selanjutnya menurut Robert S. Siegler and Geetha B. Ramani dalam penelitiannya yang berjudul Playing Board Games Promotes Low-Income Children's Numerical Development mengatakan bahwa "The numerical knowledge of children from low-income backgrounds trails behind that of peers from middleincome backgrounds even before the children enter school." Pengetahuan berhitung anak yang berasal dari keluarga berpenghasilan rendah sangat berbeda dengan anak-anak dengan latar belakang berpenghasilan menengah.

Selanjutnya menurut Roi Cohen Kadosh mengatakan bahwa "low numeracy skills have a negative impact on the employment prospects and mental and physical health of individuals, and on the economic status of countries." Keterampilan berhitung yang rendah akan memiliki dampak yang negatif pada perkembangan matematika di kelas yang lebih tinggi juga akan berdampak negatif pada prospek kerja, mental dan fisik dan kesehatan individu dan juga status ekonomi negara.

Berdasarkan hasil observasi awal saya di PAUD Alfani di kelompok B dengan jumlah anak 18 anak. 10 anak lakilaki dan 8 anak perempuan hal itu masih sangat jauh dari harapan. Pengembangan kognitif khususnya pada konsep bilangan masih banyak kesulitan. Di PAUD Alfani ini terdapat 12 orang $(70,58 \%)$ anak yang masih kesulitan dalam memahami konsep bilangan. Kesulitan-kesulitan yang dialami anak adalah seperti ketika anak diminta untuk menyebutkan bilangan-bilangan baik secara berurutan dari terkecil sampai terbesar, berurutan dari terbesar sampai terkecil, maupun ketika anak diminta menyebutkan bilangan secara acak dengan menunjuk lambang bilangannya. Anak juga belum mampu membandingkan jumlah benda dengan lambang bilangan. Ketika anak diminta untuk menyebutkan bilangan sesuai lambang, anak-anak cenderung diam dan menunggu guru memberitahu kemudian mereka mengikuti. Kesulitankesulitan yang dialami anak ini disebabkan karena keterbatasan media pendukung yang ada. Selain itu metode yang dilakukan oleh guru kelas juga cenderung masih bersifat ceramah sehingga anak kurang begitu antusias dalam mendengarkan dan memahami apa yang disampaikan oleh guru. Dalam menstimulasi atau merangsang kecerdasan kognitif anak khususnya pada konsep bilangan harusnya dilakukan dengan metode yang menyenangkan. Salah satu metode yang akan diterapkan untuk meningkatkan pemahaman konsep bilangan yaitu melalui bermain alat musik angklung.

\section{B. KAJIAN LITERATUR}

1. Bermanin Angklung

Alat musik angklung merupakan alat musik tradisional yang berasal dari Jawa Barat. Angklung termasuk alat musik melodis, yaitu alat musik yang digunakan untuk memainkan rangkaian nada atau melodi sebuah lagu.

Angklung adalah alat musik tradisional Indonesia yang berasal dari tanah sunda. Terbuat dari bambu yang dibunyikan dengan cara digoyangkan agar badan pipa bambu bertabrakan sehingga menghasilkan bunyi yang bergetar dakam susunan nada 2, 3 dampai 4 nada dalam setiap ukuran, baik besar maupun kecil. Laras (nada) alat musik angklung sebagai tradisi sunda kebanyakan adakah selendro dan pelog.

Bermain angklung sangatlah mudah sehingga angklung tidak hanya dapat dimainkan oleh orang dewasa tetapi juga dapat dimainkan oleh anak-anak usia TK. Bermain angklung juga baik dikenalkan pada anak, anak belajar untuk mencintai dan melestarikan budaya lokal 
sehingga sejak dini anak dapat mengenal apa saja kebudayaan yang dimiliki di daerahnya.

Bermain angklung sangatlah mudah sehingga angklung tidak hanya dapat dimainkan oleh orang dewasa tetapi juga dapat dimainkan oleh anak-anak usia TK. Bermain angklung juga baik dikenalkan pada anak, anak belajar untuk mencintai dan melestarikan budaya lokal sehingga sejak dini anak dapat mengenal apa saja kebudayaan yang dimiliki di daerahnya.

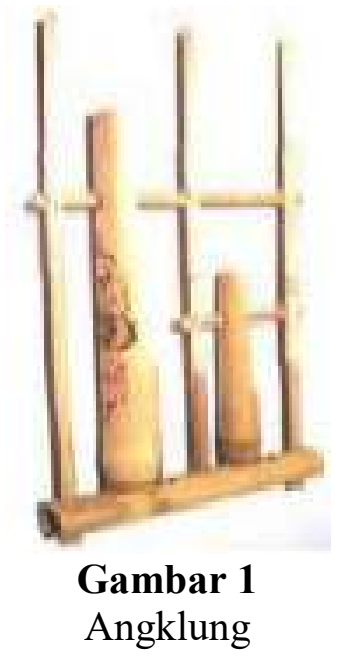

Satu buah angklung mewakili satu nada, misalnya do, re atau mi. Untuk memainkan satu aransemen lagu, tidak semua angklung dibunyikan secara bersamaan. Dalam permainan angklung ada saatnya angklung digetarkan, ada pula waktunya berhenti tergantung kepada irama lagu. Setiap anak harus disiplin menggetarkan atau menghentikan angklung yang dipegangnya sesuai dengan aransemen lagu.

"Angklung is a traditional music instrument from Indonesia that made of bamboo. Angklung consist of two bamboo tubes in a frame. The note differences of the tubes are one octave. The sound of angklung is produced from the collision between the lower part of the tube and the frame. The sound amplified by the resonator from each tube."
Angklung adalah alat musik tradisional dari Indonesia yang terbuat dari bambu. Angklung terdiri dari dua tabung bambu di bingkai. Perbedaan catatan dari tabung adalah salah satu oktaf. Suara angklung dihasilkan dari tabrakan antara rendah bagian dari tabung dan frame. Suara diperkuat oleh resonator dari masing-masing tabung.

Angklung adalah alat musik tradisional yang terbuat dari bambu dimainkan dengan cara di goyangkan dan semua orang bisa memainkanya baik anakanak maupun orang dewasa.6 Penelitian yang dilakukan oleh Novita Dwi menggunakan metode Penelitian tindakan yang berjudul "mengoptimalkan kecerdasan musikal anak usia dini dengan bermaina ngklung di sentra musik". Hasil dari penelitian ini menunjukan bahwa bahwa melalui bermain alat musik angklung dapat mengoptimalkan kecerdasan musikal pada anak. Terbukti dengan hasil pengamatan yang dilakukan telah mencapai indikator keberhasilan baik. Dari hasil penelitian ini disarankan kepada guru hendaknya dalam mengajar dapat memanfaatkan media tersebut untuk mengoptimalkan kecerdasan musikal.

Penelitian lainnya oleh Silvia mengatakan bahwa angklung adalah alat musik bambu asli Indonesia yang sangat sederhana dan sudah dikenal selama berabad-abad, yang dimainkan dengan cara menggetarkan (bunyi disebabkan oleh benturan badan pipa bambu) sehingga menghasilkan bunyi yang bergetar dalam susunan nada 2,3, sampai 4 nada dalam setiap ukuran, baik besar maupun kecil.7 Penelitian ini menggunakan metode pendekatan kualitatif dimana di TK YKA Banda Aceh sudah memiliki kegiatan ekstrakulikuler angklung. 
Senada dengan yang dikemukakan oleh Diah Rizky dalam jurnal mengatakan angklung adalah salah satu alat musik tradisional asli Indonesia yang berasal dari jawa bagian barat. Selain itu alat musik angklung mendapat sorotan istimewa dimata internasional sebagai alat musik yang sederhana namun menakjubkan, karena menghasilkan bunyi yang indah dan unik dari pipa-pipa bambu yang dibenturkan. Penelitian menggunakan metode deskriftif kualitatif dan hasil dari penelitian ini menunjukan bahwa penerapan pembelajaran angklung dengan metode angklung adalah strategi yang efektif untuk menarik minat belajar anak usia dini.

Selanjutnya penelitian yang dilakukan oleh Marlina menyatakan bahwa Angklung adalah alat musik multitonal (bernada ganda) yang secara tradisional berkembang dalam masyarakat Sunda di Pulau Jawa bagian barat. Alat musik ini dibuat dari bambu, dibunyikan dengan cara digoyangkan (bunyi disebabkan oleh benturan badan pipa bambu) sehingga menghasilkan bunyi yang bergetar dalam susunan nada 2, 3, sampai 4 nada dalam setiap ukuran, baik besar maupun kecil. Penelitian ini menggunakan metode penelitian tindakan yang menunjukan bahwa bermain musik angklung dapat meningkatkan kemampuan motorik kasar anak usia dini.

Berdasarkan pengertian di atas dapat diartikan bermain alat musik anglung adalah memainkan alat musik tradisional yang berasal dari jawa barat terbuat dari bambu dimainkan dengan cara digoyangkan sehingga menghasilkan bunyi yang bergetar dalam susunan nada 2, 3 sampai 4 pada setiap ukuran dan semua orang bisa memainkanya baik anak-anak maupun orang dewasa.

2. Pemahaman Konsep Bilangan

Pemahaman

(understand) merupakan aspek yang sangat penting $\begin{array}{ll}\text { dalam proses } & \text { penerimaan } \\ \text { pengetahuan } & \text { konseptual. }\end{array}$

Pemahaman menurut Anderson dan

Krathwohl dalam Coppola dan Primas adalah "understand is defined as constructing the meaning of instructional messeges, including oral, written, and graphic communications". Pernyataan tersebut dapat diartikan secara bebas bahwa pemahaman merupakan keberhasilan menangkap makna dalam pesan pembelajaran yang dapat berupa lisan, tulisan, dan gambar. Pernyataan tersebut memberikan gambaran bahwa agar dapat dipahami dengan baik, suatu pembelajaran yang tersaji melalui pesan tertulis, lisan, maupun gambar harus dapat memberikan makna untuk anak. Kesadaran terhadap hitungan tidak hanya menyangkut kemampuan untuk berhitung "satu, dua, tiga, dst..." dalam masa ini juga berkembang kemampuan lainnya untuk memahami bahwa satu objek berhubungan dengan objek lainnya dan dapat dipasangkan.

Pemahaman untuk berhitung juga berhubungan dengan pengetahuan terhadap strategi dalam menghitung yang berkaitan dengan menjumlah dan mengurangi. Pengembangan kemampuan dasar menghitung dapat dilakukan dengan membiasakan anak berinteraksi dengan situasi yang berkaitan dengan kegiatan menghitung, seperti:

a. Hari ini 4 anak dapat bermain dengan balok kecil;

b. Menghitung kehadiran anak di sekolah;

c. Memilih empat anak untuk membeliikan baru untuk akuarium;

d. Menata meja dengan satu piring, satu gelas dan satu serbet makan;

e. Memperkirakan berapa kali anak dapat melompat; 
f. Melakukan permainan yang mengandung giliran;

g. Mencocokan jumlah benda dengan angkanya; dan

h. Menuliskan angka sesuai dengan jumlah bendanya.

Pemahaman konsep bilangan dapat diartikan juga sebagai kemampuan mengenal dan memahami konsep bilangan, transisi dan lambang sesuai dengan jumlah benda-benda pengenalan bentuk lambang dan dapat mencocokan sesuai dengan lambang bilangan. Menurut Howden, number Sense (pemahaman bilangan) didefinisikan sebagai "intusi yang bagus pada bilangan dan saling berhubungan. Hal ini berkembang secara bertahap sebagai akibat dari mengeksplorasi bilangan, memviasualisasikannya dalam berbagai konteks, dan saling berkeitan dengan cara yang tidak dibatasi oleh algoritma tradisional". Pemahaman bilangan dan pengoprasi bilagan serta kepekaan terhadap bilangan tidak dapat terjadi cesara alami begitu saja. Konsep bilangan tidak bisa diajarkan dalam satu waktu, tetapi dibutuhkan waktu yang cukup lama, membutuhkan proses dan serangkaian pelajaran. Pemahaman konsep bilangan ini dibangun sedikit demi sedikit daru usia masih bayi sampai usia pra-sekolah, secara bertahap menjadi alat yang dapat digunakan dalam pemecahan masalah. Hal ini sangat kompleks dan berkembang secara bertahap dari waktu dan dapat dipromosikan melalui pengajaran. Salah satu konsep bilangan yang paling dekat dengan anak adalah berhitung, termasuk dua pengoprasian yaitu hafalan berhitung (rote counting) dan berhitung rasional (rational counting). Rote counting (hafalan berhitung) adalah dapat menyebutkan bilangan-bilangan dan mengingatnya. Yaitu, anak yang menyebutkan satu (1), dua (2), tiga (3), empat (4), lima (5), enam (6), tujuh (7), depalan (8), sembilan (9) dan sepuluh (10). Anak sudah dapat menghitung dengan benar dari urutan 1-10. Rational counting (berhitung rasional) yaitu memasangkan bilangan dengan benda, hal ini dapat membangun pemahaman anak terhadap konsep bilangan one-to-one corespondence. Konsep bilangan pada anak usia dini yang paling dekat dengan anak adalah menyebutkan bilangan dari 110 maupun sebaliknya 10-1, dimana anak sudah tidak kesulitan menyebutkan angka tersebut. Lebih lanjut anak dapat menggunakan bilangan untuk menghitung benda yang ada disekitarnya.

\section{METODOLOGI PENELITIAN}

Metode yang digunakan dalam tindakan ini adalah adalah model spiral Kemmis dan taggart. Pada model Kemmis \& Tagart tindakan (Acting) dan observasi (Observing) dijadikan sebagai satu kesatuan karena mereka menganggap bahwa kedua komponen tersebut merupakan dua kegiatan yang tidak bisa dipisahkan. Dimana pada penelitian ini, peneliti akan memberikan tindakan dalam rangka meningkatkan kemampuan musik melalui bermain alat musik angklung yang akan dilaksanakan dalam dua siklus. Tahapan-tahapan ini berlangsung secara berulang-ulang, sampai tujuan tercapai. Oleh karena iyu, pengertian siklus pada model ini adalah putaran kegatan yang terdiri dari empat komponen, yaitu perencanaan (Planning), tindakan (Acting), pengamatan (Observing), dan refleksi (Reflecting). Penelitian ini juga melibatkan kerjasama antara peneliti dengan guru. peneliti selain mengajar dan melaksanakan tindakan juga bertugas melaksanakan pengamatan atau active participant. Sedangkan guru membantu mengajar dan melakukan pengamatan juga sebagai kolaborator.

Teknik pengumpulan data yang dilakukan pada penelitian ini adalah observasi, wawancara, dan dokumentasi. 
Analisis data dilakuka dengan pendekatan kualitatif dan kuantitatif. Data yang berupa hasil pengamatan yang terdapat dalam catatan lapangan dianalisis menggunakan metode miles dan Huberman yaitu dengan komponen reduksi data, penyajian data dan kesimpulan. Analisis data kuantitatif menggunakan analisis statistik deskriftif yaitu analisis data dengan mendeskripsikan hasil observasi pemahaman kosep bilangan anak dalam bentuk tabel data dan grafik atau pun diagram.

\section{HASIL DAN PEMBAHASAN}

1. Proses Bermain Angklung Dalam Meningkatkan Pemahaman Konsep Bilangan

Proses bermain angklung di kelompok B PAUD Alfani dilaksanakan dalam 2 siklus. Peneliti membuat perencanaan kegiatan bersama kolabolator dan disepakati bahwa siklus I dilaksanakan sebanyak 12 kali pertemuan dengan melakukan kegiatan bermain angklung. Peneliti dan kolabolator menentukan jadwal pelaksanaan kegiatan dan menyepakati perencanaan bentuk RPPM (Rencana Pelaksanaan Pembelajaran Minggunak) dan RPPH (Perencanaan Pelaksanaan Pembelajaran Harian). Pada setiap pertemuan lagu yang akan dimainkan oleh anak berbeda-beda ini dilakukan agar anak tidak bosan dan jenuh saat bermain angklung. Pada pertemuan pertama anak diperkenalkan terlebih dahulu tentang angklung, bentuk angklung dan bagaimana cara memainkan angklung serta anak juga perkenalkan dengan not angka yang akan dimainkan.

Pada pertemuan ke 2 anak bermain angklung dengan lagu cicak-cicak di dinding dengan melihat isyarat jari guru. Pertemuan ke 3 anak bermain lagu balonku dengan melihat isyarat jari guru. Pada pertemuan ke 4 anak bermain lagu kasih ibu dengan melihat isyarat jari guru. Pertemuan ke 5 anak bermain lagu dua mata saya dengan melihat isyarat jari guru. Pada pertemuan ke 6 anak bermain angklung lagu lihat kebunku dengan melihat isyarat jari guru. Pada pertemuan ke 7 anak bermain angklung lagu pelangipelangi dengan melihat isyarat jari guru. Pada pertemuan ke 8 anak bemain angklung lagu satu-satu aku saying ibu dengan melihat isyarat jari guru. Pada pertemuan ke 9 anak bermain angklung lagu kasih ibu dengan melihat isyarat jari guru. Pada pertemuan ke 10 anak bermain angklung lagu topi saya bundar dengan melihat isyarat jari guru. Pada pertemuan 11 anak bermain angklung lagu topi saya bundar dengan melihat isyarat jari guru. Pada pertemuan 12 anak bermain angklung lagu ibu kita kartini. Pada pertemuan terakhir guru dan peneliti menentukan siapa anak yang skornya palingbanyak dan siapa anak yang skornya paling sedikit. Pada siklus II, berdasarkan hasil diskusi antara peneliti dan kolabolator dilaksanakan 12 kali pertemuan dengan menggunakan kegiatan bermain angklung. Pelaksanaannya hampir sama tetapi ada beberapa tindakan yang berbeda dengan siklus I karena disesuaikan dengan hasil refleksi pada kegiatan siklus I. Perbedaan tersebut diantaranya: pada siklus I Guru lebih banyak berperan aktif dalam pembelajaran sedangkan pada siklus II Anak lebih berpartisipasi aktif dan guru bertindak sebagai fasilitator dan motivator saja. Pada siklus I Anak bermain angklung secara serentak dan bersama-sama sedangkan pada siklus II Anak bermain angklung dibagi menjadi 2 kelompok yang terdiri dari 8 orang anak. Pada siklus I Guru memberikan instruksi pada anak dengan isyarat jari sedangka pada siklus II Guru hanya menunjuk bilangan pada not angka di papan tulis sebagai instruksi. Pada siklus I 
Guru kurang memberikan perhatian pada anak yang kurang aktif sedangka pada siklus II Guru memberikan perhatian pada anak yang kurang aktif. Pada siklus I Anak lebih fokus bermain angklung daripada mengembangkan pemahaman konsep bilangan sedangkan pada siklus II Anak bermain sambil mengembangkan pemahaman konsep bilangan.

2. Hasil Pengamatan Bermain Angklung Dalam Meningkatkan Pemahaman Konsep Bilangan

Hasil penelitian yang dilaksanakan saat penelitian pada anak kelompok B PAUD Alfani dengan responden 18 orang anak menunjukan peningkatan pada pemahaman konsep bilangan anak. Data kuantitatif peningkatan pemahaman konsep bilangan pada prasiklus, siklus I dan siklus II disajikan pada tabel dibawah ini:

\section{Tabel 1}

Data pemahaman konsep bilangan anak kelompok B PAUD Alfani Tahun 2017 Dari Prasiklus, Siklus I Dan Siklus II

\begin{tabular}{|c|c|c|c|c|c|c|c|c|c|c|}
\hline \multirow[b]{2}{*}{ No } & \multirow[b]{2}{*}{ Nare. } & \multicolumn{2}{|c|}{ Fradtux } & \multicolumn{2}{|c|}{ shun i } & \multicolumn{2}{|c|}{ scesil } & \multicolumn{3}{|c|}{ Persentase } \\
\hline & & $T C P$ & 5 & 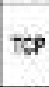 & $x$ & 108 & $x$ & $\begin{array}{c}\text { Prokin } \\
\text { ske } \\
\text { sobusi }\end{array}$ & $\begin{array}{c}\text { ghus! } \\
\mathrm{Ke} \\
\text { sotus I }\end{array}$ & 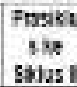 \\
\hline$i$ & AS & 78 & 44 & $\%$ & 652 & $\pi$ & का: & 296 & 314 & 5114 \\
\hline 2 & 뻬 & 13 & $4 \pi$ & $\gamma$ & $\cos x$ & 8 & $\mathrm{get}$ & 1528 & 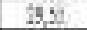 & ir, is \\
\hline 3 & $\mathrm{FE}$ & 13 & 3150 & SI & $C_{2}$ & 78 & 38: & 20 & 324 & $5 ! 114$ \\
\hline 4 & 34 & 7 & 573 & 4 & 545 & 73 & 85 & $163 ?$ & कर & 29 \\
\hline 2 & $5 A$ & It & 851 & 8 & 25,8 & H & $3 t \mathrm{E}$ & 143i & 1191 & 21,13 \\
\hline E & $5 \mathrm{Y}$ & 42 & 273 & S! & 727 & 5 & $07 \pi$ & 20 & $3 x$ & कo \\
\hline$T$ & $x$ & 3 & 251 & $x$ & 15,8 & 4 & 38 & 1477 & 114 & a, 13 \\
\hline 5 & $M$ & 5 & $\$ 677$ & 7 & $\mathrm{~B}, 4$ & 5 & 523 & 7355 & 78 & dit5 \\
\hline 5 & SH & i) & xes & 8 & 420 & 25 & 0090 & $14 \overline{7}$ & 1,2 & 51,22 \\
\hline D & DH & 43 & 355 & $s$ & $15 x$ & 5 & $9 \pi$ & $x y$ & 227 & B85 \\
\hline II & AS & 4 & 34 & $\frac{1}{4}$ & 158 & 73 & $8(5)$ & 1765 & 314 & - 9.18 \\
\hline 12 & VI: & I: & 2015 & W & $22, \pi$ & 21 & ox & 117 & $13 \pi$ & 310 \\
\hline B & IID) & 4 & $3 t^{2}$ & $x$ & 5523 & 78 & 85 & is 3 & 35 & Xon \\
\hline H & 8 & 9 & Cos & 5 & Ex & 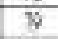 & $8 \%$ & $\times 45$ & $22 \pi$ & 4.75 \\
\hline 15 & 18 & It & 851 & 51 & $13 \Omega$ & $\pi$ & 3190 & $15 x$ & 211 & $x 39$ \\
\hline 15 & $\overline{F B}$ & 33 & 579 & $\alpha$ & 958 & 72 & 812 & 158 & S纟it & 432 \\
\hline 1? & $x$ & 3 & A15 & $x$ & $65 x$ & 15 & 83 & 147 & 355 & 4.12 \\
\hline 13 & EI & 35 & $x \pi$ & 5 & $23 x$ & 3 & 531 & 15 32 & 개홍 & 50,00 \\
\hline \multicolumn{2}{|c|}{ ind } & Q6: & 21,3 & औह & $\begin{array}{l}\text { ixe, } \\
\text { I2 }\end{array}$ & Let & $\begin{array}{l}15+2 \\
61\end{array}$ & $s 1,13$ & 41137 & $516,2:$ \\
\hline \multicolumn{2}{|c|}{ poret } & 53 & $4 \%$ & $\begin{array}{c}733 \\
3\end{array}$ & W. & $1: 33$ & $5: \notin]$ & 1532 & $6 x$ & 4550 \\
\hline
\end{tabular}

Berdasarkan tabel 1. di atas, pada prasiklus Pada prasiklus rata-rata skor anak sebesar 40,09\% meningkat pada siklus I sebesar $59,41 \%$ dan meningkat lagi pada siklus II sebesar 85,61\%.
Berdasarakan data tersebut, maka peningkatan pemahaman konsep bilangan telah mencapai hasil yang disepakati peneliti dan kolabolator serta menunjukan bahwa bermain angklung dapat meningkatkan pemahaman konsep bilangan pada anak kelompok B PAUD Alfani tahun 2017. Meningkatknya pemahaman konsep bilangan pada siklus II dan secara klasikal semua anak sudah memenuhi kriteria keberhasilan sesuai kesepakatan peneliti dan kolabolator menunjukan kegiatan bermain angklung dapat meningkatkan pemahaman kosep bilangan anak.

Analisis data kualitatif dibuat berdasarkan hasil catatan lapangan, wawancara, dan dokumentasi dengan tahapan reduksi data, display data, dan penarikan kesimpulan. Berikut ini pemaparan data kualitatif dari indikator-indikator bermasalah pada penelitian ini dengan tindakan bermain angklung dalam meningkatkan pemahaman konsep bilangan anak kelompok B PAUD Alfani tahun 2017.

Berdasarkan hasil pengamatan peneliti dan kolabolator maka dapat disimpulkan bahwa penerapan bermain angklung dapat meningkatkan pemahaman konsep bilangan pada anak kelompok B PAUD Alfani Bogor tahun 2017. Indikator mencocokan jumlah benda dengan lambang bilangan pada anak mengalami kemajuan dari pra siklus ke siklus I dan siklus II. Adapun hal yang terlihat dari, pertama, anak mencocokan jumlah benda dengan lambang bilangan bersama-sama dan dibantu oleh guru, kedua, anak mencocokan jumlah benda dengan lambang bilangan bersama-sama tanpa dibantu oleh guru, ketiga, anak mecocokan jumlah benda dengan lambang bilangan dalam lembar kerja yang diberikan guru. 
3. Pembahasan

Dari berbagai indikator yang telah dikemukakan bahwa anak-anak sangat senang dan menikmati kegiatan yang dilakukan dengan kegiatan bermain angklung. Anak menjadi lebih bersemangat ketika melakukan kegiatan di dalam kelas, anak juga terlihat senang dan mudah memahami materi pemahaman konsep bilangan yang diberikan oleh guru. Guru juga memberikan bantuan dan arahan ketika ada anak yang belum mampu mengerjakan kegiatan pemahaman konsep bilangan.

Peningkatan pemahaman konsep bilangan anak yang semankin meningkat pada setiap siklusnya, merupakan bukti bahwa kegiatan bermain angklung efektif dilakukan. Pelaksanaannya sederhana, memiliki interaksi antara guru dan anakanak ataupun sesama anak-anak membuat anak memiliki pengetahuan yang bertambah dalam waktu yang singkat. Saat bermain angklung, anak tanpa sadar belajar konsep bilangan dari not angka yang diberikan oleh guru, anak juga lebih senang karena bisa belajar sambil bernyanyi dan tidak monoton hanya dengan lembar kerja saja. Hal ini merupakan satu kelebihan pembelajaran menggunakan kegiatan bermain angklung dibandingkan dengan metode pembelajaran yang lainnya.

Hasil penelitian yang ada memiliki keterkaitan dengan beberapa disiplin ilmu lain. Jika dilihat dari kagian pedagogik, nilai edukatif yang terkandung di dalam proses pembelajaran menggunakan kegiatan bermain angklung untuk meningkatkan pemahaman konsep bilangan adalah anak disangga dengan kegiatan bermain yang kontekstual dan menyenangkan untuk memahami sesuatu dalam hal pemahaman konsep bilangan (Scaffolding). Dalam bermain angklung, anak secara aktif terlibat dalam setiap kegiatan yang secara tidak sadar meningkatkan pemahamannya tentang sesuatu, dan mengenal halhal yang ada didekatnya. Hal ini sesuai dengan pendapat dari Vygotsky "children's creation of imaginary situations, whisc derive from real life tensions". Semua aktivitas bermain repsesentasional menciptakan situasi imajiner, bermain representasional memuat aturan-aturan berprilaku yang harus diikuti oleh anak. Menurut Vygotsky bermain adalah kegiatan yang dilakukan dengan atau tanpa menggunakan alat yang menghasilkan pengertian atau memberikan informasi, memberikan kesenangan maupun mengembangkan imajinasi pada anak. Jika pengertian bermain dipahami dan sangat kita kuasai, maka kemampuan itu akan berdampak positif pada cara kita dalam membantu proses belajar anak. Pengamatan ketikan anak bermain secara aktif maupun pasif, akan banyak membantu memahami jalan pikiran anak, selain itu juga akan meningkatkan keterampilan berkomunikasi.

Salah satu konsep mendasar dalam matematika adalah pemahaman konsep bilangan. Pemahaman ini lebih kepada bagaimana anak membangun sebuah makna tentang konsep bilangan dari kegiatan bermain yang dilakukan oleh anak saat diluar kelas maupun didalam kelas. Pemahaman konsep bilangan mulai diperkenalkan sejak usia dini pada anak, sehingga pada usia selanjutnya anak dapat berkembang dengan baik dan dapat mempengaruhi perkembangan kemampuan matematika pada umumnya dan pada tingka pendidikan yang lebih tinggi. Menurut penelitian yang dilakukan oleh Viorel Agheana menyatakan bahwa "Mathematical skills are 
based on the concept of number. Understanding the number concepts and basic mathematical skills so that they can be used in daily activities is an important part of the education of children from the preschool period." Kemampuan matematika didasarkan pada konsep bilangan. Memahami konsep jumlah dan dasar keterampilan matematika sehingga mereka dapat digunakan dalam kegiatan sehari-hari merupakan bagian penting dari pendidikan anak-anak dari periode prasekolah. Matematika bagi anak usiadini adalah cara mereka melihat dunia dalam pengalaman mereka. Cara dalam memecahkan permasalahan yang nyata. Itu merupakan bagian pemahaman tentang bilangan, operasi bilangan dan fungsinya. Konsep bilangan anak usia dini berkembang cukup pesat antara usia sekiratan tiga sampai enam tahun. Untuk anak usia empat tahun mereka bisa membedakan antara kecil dan menengah dan besar. Tetapi mereka mengalami kesulitan dalam membandingkan ukuran medium (sedang) dan ukuran besar.

\section{E. SIMPULAN DAN REKOMENDASI}

1. Simpulan

Pertama, Proses peningkatan pemahaman konsep bilangan anak kelompok B dilakukan melalui penerapan kegiatan bermain angklung, dimana penelitian ini dilakukan dalam dua siklus. Pada awal kegiatan siklus I, guru mengenalkan terlebih dahulu alat musik angklung dan guru memperlihatkan kepada anak-anak bagaimana caranya memainkan angklung, guru juga mengenalkan terlebih dahulu not angka do, re, mi, fa, sol, la, si, do. Seletah anak mengerti not angka selanjutnya guru memberikan angklung kepada anak-anak sesuai dengan angka yang tertera di angklung agar anak paham dan mnegerti bahwa bermain angklung ini sesuai dengan not angka yang akan guru tulis di papan tulis, kemudian guru menuliskan not angka di papan tulis, anak memperhatikan not angka di papan tulis dan anak membilang bilangan not angka yang ada di papan tulis, setelah itu guru memberikan kode kepada anak untuk memainkan angklung berupa kode jari guru pada anak sehingga secara tidak langsung anak akan menyanyikan satu lagu menggunakan angklung. Setelah bermain angklung barulah kegiatan peningkatan pemahaman konsep bilangan dilakukan oleh guru, dimulai dari mengurutkan bilangan 1-10 secara berurutan, mengurutkan benda dari yang terkecil sampai yang terbesar, mengelompokan bentuk angklung yang besar, menunjukan benda yang lebih banyak dan benda yang lebih sedikit, mencocokan bilangan dengan lambang bilangan yang sama, membedakan mana bilangan yang lebih kecil dan bilangan yang lebih besar, memahami efek penambahan dari suatu benda, memahami efek pengurangan dari suatu benda dan menyebutkan hasil pengurangan dan penambahan bilangan sampai 10 . Pelaksanaan tindakan pada siklus II dilakukan dengan cara yang sama hanya saja ada sedikit perbaikan berdasarkan hasil refleksi yang dilakukan peneliti bersama dengan kolabolator dari pelaksanaan tindakan pada siklus I. Adapun perbedaan dari siklus I dan siklus II adalah pada saat siklus I anak bermain angklung secara bersamasama dan tidak dipisah, pada siklus II anak bermain angklung dipisah menjadi dua kelompok supaya anak bisa melihat temannya bermain angklung. Kemudian, pada siklus I guru memberikan arahan pada anak saat bermain angklung dengan menggunakan jari, pada siklus II guru memberikan arahan pada anak melalui not angka yang tertera pada papan tulis jadi guru hanya 
PEDAGOGIA : Jurnal IImu Pendidikan

menunjuk bilangan dan anak harus membunyikan angklung sesuai dengan bilangan yang ditunjuk guru.

Kedua, Hasil dari kegiatan dengan menggunakan kegiatan bermain angklung dapat meningkatkan pemahaman konsep bilangan anak kelompok B PAUD Alfani tahun 2017. Hal tersebut dibuktikan dengan meningkatnya TCP pemahaman konsep bilangan anak dari prasiklus ke siklus I hingga siklus II. Penelitian ini mengalami peningkatan dari rata-rata TCP anak pada prasiklus sebesar $40,09 \%$ mengalami peningkatan pada siklus I yang memiliki TCP rata-rata sebesar $59,41 \%$ dan mengalami peningkatan di siklus II dengan rata-rata TCP sebesar $85,61 \%$. Hal ini terbukti bahwa penerapan kegiatan bermain angklung dapat meningkatkan pemahaman konsep bilangan anak.

2. Rekomendasi

Berdasarkan kesimpulan yang telah dikemukakan, adapun implikasi dari penelitian ini adalah:

a. Bagi Guru

Penelitian ini diharapkan bermanfaat untuk guru saat proses pembelajaran konsep bilangan. Penelitian ini juga diharapkan membantu guru untuk mengoptimalkan kemampuan pemahaman konsep bilangan melalui bermain angklung.

b. Bagi Anak

Penelitian ini dapat meningkatkan kemampuan pemahaman konsep bilangan anak melalui metode bermain angklung. Keterlibatan anak secara langsung pada saat bermain angklung bisa memberikan stimulasi yang baik terhadap pemahaman konsep bilangan anak karena anak mengalami langsung saat bermain angklung.

\section{DAFTAR PUSTAKA}

Diah Rizky Kartika Putri. Pembelajaran Angklung Menggunakan Metode Belajar Sambil Bermain. (jurnal nasional).

Julie Coppola dan Elizabeth V. Primas. One Classroom, Many Learners (Hawaii: International Reading Association Inc. 2009).

Lestari, Novita D. Mengoptimalkan kecerdasan musikal anak usia dini dengan bermain alat musik angklung disentra musik. Jurnal.

Marlina. Peningkatan Kemampuan Motorik Kasar Anak Melalui Permainan Alat Musik Angklung Pada anak Usia 5-6 tahun. (jurnal Portal Garuda).

Martini jamaris. Perkembangan dan Pengembangan Anak Usia Taman Kanak-Kanak. (2004). Jakarta: PPS UNJ.

Pirji Aunio, Markku Niemivirta., Predicting Children's Matematical Performance in grade one by early numeracy., (finiland, 2010) jurnal sience direct.

Robert S. Siegler and Geetha B. Ramani. Playing Board Games Promotes Low-Income

Children's Numerical Development. Pittsburgh.

Roi Cohen Kadosh, Ann Dowker , Angela Heine, Liane Kaufmann, Karin Kucian, Interventions for improving numerical abilities: Present and future. (2013). Jurnal sience direct.

Silviani. Kegiatan ekstrakulikuler angklung pada anak usia dini di TK YKA (Yayasan Kesejahteraan Anak) Banda Aceh. (jurnal, 2014). 
PEDAGOGIA : Jurnal Ilmu Pendidikan

Sudarso. Anugrah S. Comparison between psycho- Acoustics and Physio Acoustic Measurement to Determine Optimum Reverberation Time of Pentatonic Angklung Music Concert Hall Ebsco (jurnal ebsco.Indonesia).

Susan Sperry Smith. Early Childhood Mathematic 4th Edition (New York: Perason Education Inc, 2009). 